\section{A new species of the genus Schiffnerula (Englerulaceae) from Kerala, India}

\section{V.B. Hosagoudar ${ }^{1} \&$ G.R. Archana ${ }^{2}$}

1,2 Tropical Botanic Garden and Research Institute, Palode, Thiruvananthapuram, Kerala 695562, India

Email: ${ }^{1}$ vbhosagoudar@ rediffmail.com

During a survey of foliicolous fungai of Kerala, a species of the genus Canthium was found infected with a black mildew fungus. Critical microscopic study of the fungus revealed that it belonged to an undescribed species of the genus Schiffnerula Höhn. and hence, it is described and illustrated in detail.

\section{Schiffnerula canthii sp. nov.}

(Fig.1)

Coloniae epiphyllae, subdensae, ad $2 \mathrm{~mm}$ diam., confluentes. Hyphae flexuosae, oppositae, alternatim vel irregulariter acuteque vel laxe ramosae, laxe vel arte reticulatae, cellulae 11-27 x 6-8 $\mu \mathrm{m}$. Appressoria alternata, unilateralis, globosa, sessilis, integra, 9-15 x 8-15 $\mu \mathrm{m}$. Conidia Questieriella dispersa, pallida brunnea, fusiformes, curvula, 3-septata, constricta ad septata, attenuata ad ambi apicem, 40-48 x 11-15 $\mu \mathrm{m}$. Conidiophora Sarcinella micronemata, simplices, ramosa, recta vel flexuosa, pallid brunnea, 0-2- septata, 12-40 × 5-8 $\mu \mathrm{m}$ diam.; cellulae conidiogenae monoblasticae, integratae, plerumque terminalis, cylindracae; conidia solitaria, sicca, simplices, subspherica vel sarciniformis, 28 cellula, brunnea ad initio, nigra ad maturitata, sarcinatim septata, constrictae ad septata, $20-40 \mu \mathrm{m}$ diam., parietus glabrus. Thyriothecia pauca, orbicularis, ad $75 \mu \mathrm{m}$ diam.; asci non visa; ascosporae oblongae, conglobatae, brunneae, uniseptatae, constrictae, 22-26 x 8-13 $\mathrm{m}$, parietus glabrus.

Colonies amphigenous, subdense, up to $2 \mathrm{~mm}$ in diameter, confluent. Hyphae flexuous, branching opposite, alternate to irregular at acute to wide angles, loosely to closely reticulate, cells 11-27 x 6-8 $\mu \mathrm{m}$. Appressoria alternate, unilateral, globose, sessile, entire, 9-15 x 8-15 $\mu \mathrm{m}$. Conidia of Questieriella scattered, pale brown, fusiform, curved, 3-septate, constricted at the septa, tapering towards both ends, 40-48 x 11-15 $\mu \mathrm{m}$. Sarcinella conidiophores

Date of online publication 26 July 2009

ISSN 0974-7907 (online) | 0974-7893 (print)

Editor: R.K. Verma

Manuscript details:

Ms \# 02062

Received 13 September 2008

Finally accepted 19 June 2009

Citation: Hosagoudar, V.B. \& G.R. Archana (2009). A new species of the genus Schiffnerula (Englerulaceae) from Kerala, India. Journal of Threatened Taxa 1(7): 378

Copyright: (C V.B. Hosagoudar \& G.R. Archana 2009. Creative Commons Attribution 3.0 Unported License. JoTT allows unrestricted use of this article in any medium for non-profit purposes, reproduction and distribution by providing adequate credit to the authors and the source of publication.

Acknowledgement: We thank the Director, Tropical Botanic Garden and Research Institute, Palode, Thiruvananthapuram, Kerala for the facilities. We are grateful to the Ministry of Environment and Forest, New Delhi for financial support and to the Forest Department, Govt. of Kerala for forest permission. micronematous, simple, branched, straight to flexuous, pale brown, $0-2$ septate, $12-40 \times$ 5-8 $\mu \mathrm{m}$; conidiogenous cells monoblastic, integrated, mostly terminal, cylindrical; conidia solitary, dry, simple, subspherical to sarciniform, 2-8-celled, brown when young, carbonaceous black at maturity, sarcinately septate, constricted at the septa, $20-40 \mu \mathrm{m}$ in diameter, wall smooth. Thyriothecia few, orbicular, up to $75 \mu \mathrm{m}$ in diam.; asci not seen; ascospores oblong, conglobate, brown, uniseptate, constricted at the septum, 22-26 x 8-13 $\mu \mathrm{m}$, wall smooth.

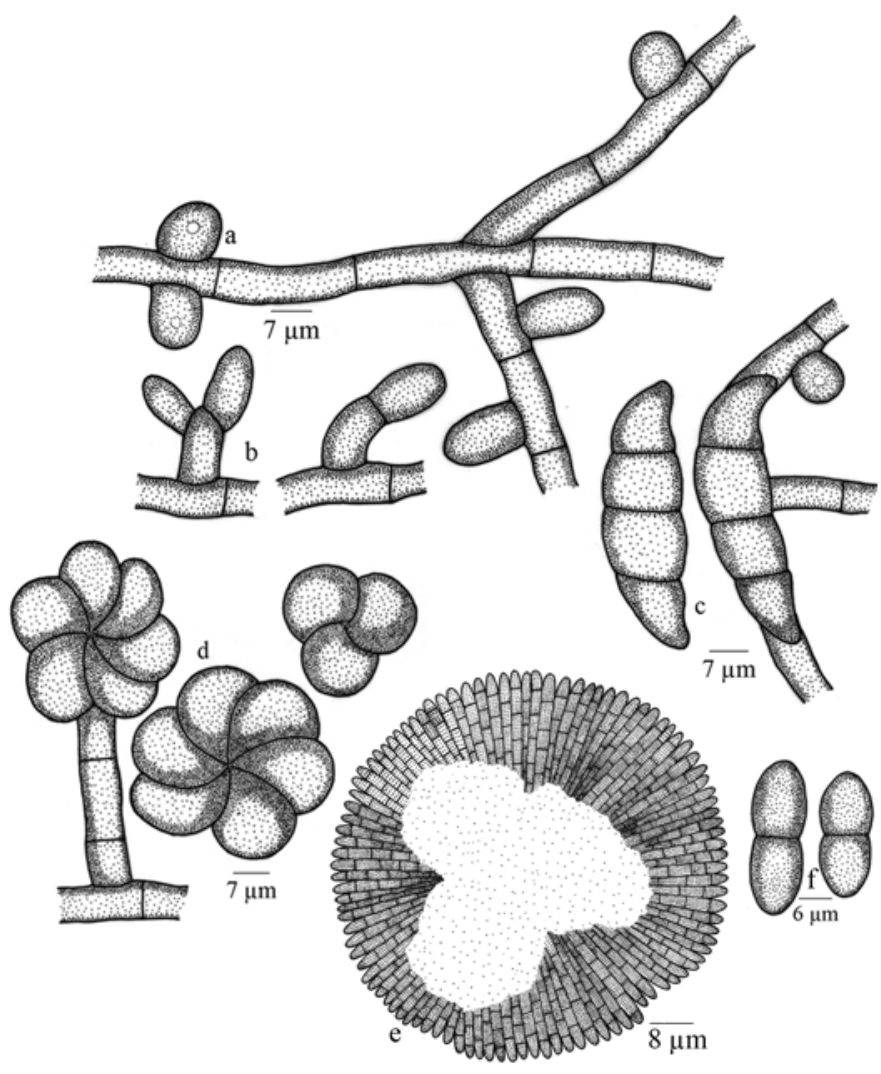

Figure 1. Schiffnerula canthii sp. nov.

a - Appressorium; b - Conidiophore; c - Conidia of Questieriella (one germinating); d - Conidiophore and conidia of Sarcinella;

e - Thyriothecium; $f$ - Ascospores

Etymology: Named after the host

\section{Material examined}

Type: 20.ii.2007, On leaves of Canthium sp. (Rubiaceae), Ponmudi, Thiruvananthapuram, Kerala, India, coll. G.R. Archana et al. HCIO 48164 (type), TBGT 2900 (isotype). (MycoBank \# MB5 13419).

Schiffnerula craterispermi (Hansf.) S. Hughes, S. hendrickxii (Hansf.) S. Hughes, S. psychotriae (Doidge) S. Hughes, S. palicoureae (M.L. Farr.) S. Hughes and S. ugandensis (Hansf.) S. Hughes are known on different host genera of the family Rubiaceae (Hosagoudar 2003). So far there is no record of the genus Schiffnerula on the host genus Canthium. Based on the host specificity, the present fungus has been accommodated in a new species.

\section{Reference}

Hosagoudar, V.B. (2003). The genus Schiffnerula and its synanamorphs. Zoos' Print Journal 18: 1071-1078. 